\title{
On Competitiveness of Educational Organizations
}

\author{
Elena Blagireva \\ Russian State Specialized Arts Academy \\ Moscow, Russia \\ e-mail: blagireva@list.ru
}

\begin{abstract}
Innovative development of any organization is a creative approach for the young, active and professional highly qualified specialists. It's an active search for effective mechanisms for universities' adaptation to new realities, allowing to increase educational quality if necessary to increase the efficiency of educational institutions. This article is an evaluation of the competitive position a university is given and also a model of effective implementation of marketing instruments into educational institutions in order to increase and improve its activity and optimize it.
\end{abstract}

Keywords-competitiveness; effectiveness; modernization; innovation development; internationalization; human resource; human potential; education

\section{INTRODUCTION}

In times of crisis of our society it becomes obvious that the Russian education system needs to be modernized.

Globalization has made economic growth one of the most important factors for success. This means that we educational institutions now compete with each other both on the national and international market which allows worldwide education to improve.

Growth speed increase and its stability are impossible without improvement of the education system, human resource and innovative policy.

The system of education literally forms a personality, a life style and plays an important role in the new generation of professionals' development $\{2\}$. Since the economy is growing more and more intellectually, there is a close connection between education and the economy, which is expressed not only in human resource development, but also in economic growth, population income increase and satisfaction of the market's need for highly qualified specialists.

In a considerably short time period we watched an educational boom of higher education, the number of private universities and the student's number increased. An opportunity of free choice of a university, providing the specialist's preparation, as well as variety of programmes and forms of access to higher education led to the competition increase between universities and the number of students. All this demands absolutely different organization of higher school activity, new approaches and solutions and active effective mechanisms for the universities' adaptation to new realities.
We have every chance to do it. An efficient promotion of educational services in the market and such functions as information, consulting, educational services realization and resource support of education are strongly supported by a wide range of mediators. Among them there are employment services, labour stock exchanges, registration organs, licensing and accreditation of educational organizations, educational foundations, educational institutions associations, specialized educational centres, etc.

Besides, the modern market of educational services suggests an important role of the state for management. The state usually creates, supports and enforces public opinion, educational institutions' positive image, educational financing and long-term investments, taxation benefits and other market regulation forms in order to develop priority specializations, forms and methods of specialist's preparation, education in general, licensing and attestation of educational institutions and different assortments of educational programmes.

Yet, to win in a tough competition, universities have to develop and present a well thought through, efficient marketing policy of its services to the consumers.

Marketing methods have been implemented in business, economy and advertisement for over twenty years in this country. Meanwhile education and commerce were perceived by the public opinion as antagonists. Probably, that is why marketing instruments have been weakly used in education so far.

\section{REASONS FOR TOO LITTLE COMPETETIVENESS}

The term of competitiveness is widely used in cases where private or industrial goods, work or services are mentioned. But in higher educational institutions' evaluation this term is seldom used $\{3\}$. This has a number of reasons.

First, services, provided by universities, can be different. Their specific lies in their deep social orientation.

Secondly, the higher schools, being mediators of everything new and leading, has very conservative structures. By conservatism we mean selecting and keeping of the best native and foreign traditions in education.

Thirdly, there is a special competition character between the universities. As a rule, every university has its own unique history, well-kept traditions, adopted in the long time of educational history. Many universities often do not need additional advertising, since any change in the university's 
structure either for the good or for the bad cannot help being noticed by the society.

Fourthly, in a planned economy country there was no definite need to evaluate a university's current position, since general planning defined the role and place of every university in the education system. Changing the economic situation made the universities face new objectives and the universities felt more freedom in their realization.

\section{DETERMINING COMPETITIVENESS}

One of the traditional approaches to an organizational competitiveness evaluation is its market share evaluation, which is determined as a combination of the services volume of the regional market of educational service. $\{8\}$.

Yet, a market share, which is possessed by a university today, does not characterise adaptation means of an organization, a university's ability to oppose market sharing by other competitors.

That's why an evaluation system is needed, which could characterize the university's potential and its competitive opportunities.

Special attention should also be given to a concept according to which the university's competitiveness is defined first of all by its image.

That is why during competitiveness' evaluation of a university an analysis of its business potential is needed.

In the author's opinion a good or a service can be competitive if its general useful effect for a spending unit is higher than the others and the measure of one of the criteria is accepted by a consumer.

Considering competitiveness as an important factor of goods and services realization in the market, there are four competitiveness levels. The first level is a good or service competitiveness, the second is company competitiveness, the third is industry competitiveness and the fourth is a country's competitiveness. A suggested classification is based upon micro and macro economic analysis, meanwhile there is a more general approach, which was initiated by the Russian Sciences Academy academician Yu.V. Yeremenko (multi-level economy theory). This approach suggests the necessity of research of competitiveness in the middle level as well as analysis of the features of the notion " university competitiveness".

Important Western specialists in the management area M.X. Meskon, M.Albert and F. Hedowry remark that a management's efficiency is that " a company makes something better than its competitors, which means it keeps its competitiveness", which allows to attract and keep consumers $\{5\}$. In F. Kotler's opinion an organizational competitiveness means that a guarantee of it's aims achievement is the definition of the needs of the focus markets and providing them with the necessary satisfaction of a more efficient and more productive than the competitors. $\{4\}$.

\section{REACHING COMPETITIVENESS}

\section{A. Different Approaches to Competetiveness}

Globalization tendencies raise an important issue for any institution of higher education: how to reach a competitive advantage and to keep it in the competitive environment. The term of competitive advantage in this context is how to get advantage by means of resource consolidation and their more efficient organization. It is considered that more than half of all the existing organizations offering their services to consumers in this education segment possess a competitive advantage.

Many organizations develop different approaches to achieve competition advantage. Some of them put quality and stability at stake; others focus on resource concentration for new technologies' integration. In spite of different approaches, most of the strategies are similar. Thus, in1980s a domineering theory in the strategies' development was a competitive forces approach, developed by Harvard Business School professor Michael Porter. The author stated that organisational activities should be aimed at external competitions through beneficial market positioning. Product or service differentiation is meant by external competences as a result of a great variety of offer. Usually in such a practice the analysis objects are particular goods or services. As a rule, such a management method discusses positioning issues, basic cost, etc. Another approach accentuates its focus upon a competitive advantage creation, based upon the interior efficiency of organizational activity (resourcebased view). It is suggested that a long-term advantage over a competitor is realized via interior competences increase and the activity results. This concept means a development of organizational changes concerning the strategy's issues. Such an approach suggests first of all specific opportunities defining the activity's success. A specific feature of this approach is that an organization which reached a high growth may compete in any market. Since its leading competencies influence the success of a whole line of services, in order to improve its growth potential a corporation should then transit from an idea of itself as a number of final products to self-realization as a core competences centre. Thus, competition moves from opposition of " a good vs. a good" towards " a company vs. a company". Core competences are what a company can do better than the competitors.

In recent years another theory appeared, called "dynamic capabilities paradigm". This concept is a generalized approach to the new sources of competitive advantage understanding. Dynamic capabilities paradigm defines in what direction the existing interior and exterior competition forms can be increased in order to compliance the environment. The management uses its dynamic capabilities for uniting, constructing and reforming interior and external competences. The basis of dynamic capabilities is an organization's orientation to the processes and not to markets. Thanks to such an approach corporate competences can be created depending on the chosen strategy and the kind of competition. 


\section{B. Importance of Core Competences}

It may be noted that all the above mentioned strategic approaches suggest that a competitive advantage is based upon internal and external core competences, which provide an opportunity to reach competitiveness as an organisation or a company and to support it. Such a strategy suggests standard control, a system compatibility of products and services and functional team work. Such competences are based on experience, knowledge, efficient management and do not lose its value from utilizing it. On the other hand such competences need perfection, their experience is lost without using them. Constantly changing conditions of a competitive environment will sooner or later make modern core competencies inadequate. Logically, competitiveness depends on future competences' creation. But in order to create competences for tomorrow special qualities are necessary: dynamic opportunities. The creation of core competencies demands skill accumulation and integration, both inside and outside an organization. That is why an ability to integrate a varied experience is as important as an ability to generate the new.

Dynamic opportunities are an ability to integrate experience, to develop and reform external and internal competences in order to match a changing world demands. Thus, dynamic opportunities reflect an organizational ability to create new leading core competences in a particular environment.

In order to understand its opportunities, it is necessary to consider not the financial resources, but organizational structures and management processes, which support the core competencies, forming new opportunities. There is also a way to get a competitive advantage through a monopoly position in the market. Yet, such an approach may hardly be considered a competitive strategy in management; it is rather a political art.

Considering the issues of core competencies and dynamic opportunities for gaining a competitive advantage it is necessary to also mark an importance of the system of corporate values, which means organizational norms and values shared by all employees. Such strategies, allowing a company to gain a competitive advantage refer to the strategy of development management of educational institutions, most of which function in a particular environment.

\section{SPECIFICS OF REgIONAL RUSSIAN UNIVERSITIES}

Globalization questioned the education quality and its evaluation process. One of the widely discussed issues is what education system can be considered a successful one? A general answer is easy enough: the higher education system has to be in compliance with the demands of the quickly changing world of professional activity. Finally educational standards, methods and the whole educational process are to be improved in order to compare the acquired skills and knowledge to the market's needs.

The experience of recent years proves that not every regional university is ready to work in a competitive environment. Even an opportunity to provide competitive educational services does not allow the universities to realize its advantage because of the lack of practice of utilising of all the complex of marketing means: a flexible policy in forming of a number of professions, a loyal price range policy, tight and reliable connections with enterprises and organizations, providing working places for graduates, effective organizational methods of the educational process and succession of pre-university and university education.

At the same time, a market demand in regional markets is complicated because of the slow movement of the market borders and non-governmental educational institutions involvement, which utilise actively an experience of foreign universities and work in competition conditions. A direct utilisation of this experience in Russian universities is complicated because of its uniqueness and lack of universal schemes of competitive behaviour in the educational services market.

In modern conditions every university has to correctly evaluate the current market situation in order to suggest effective competition methods. On one hand they would respond to the current market situation in Russia, on the other hand to the needs of a particular university, regional first of all. The first and the most difficult stage of work is to analytically consider the ways to achieve competitive advantages. Here, among modern marketing problems, special marketing problems acquire the following tasks: finding out marketing environment characteristics and analysing other universities' activity and the competitive position of the university's specialization in the market of educational services.

As Yu.A. Moskvichev and S.A. Razumov mark $\{6\}$ "in the last five years there is a competitive environment of higher education". According to these authors, it is necessary to form a highly technical educational environment, which provides:

- a high level of educational services quality;

- educational costs minimization;

- market mobility.

In order to make a regional system of higher education competitive in the Russian market of educational services it is necessary to provide the necessary locational conditions and provide competitiveness of educational institutions. A region should be attractive not only for universities but also for population. That is why such ideas as "knowledge regions" or "knowledge towns" become important as well as national universities based on a mega-university.

\section{SUGGESTED FACTORS OF COMPETITIVENESS}

Considering already existing approaches of Russian and foreign scientists in competitiveness evaluation it is suggested to combine all the results of the university's activity and its structural divisions to be divided into six groups:

- Economic ranges show the combination of the results and the spent resources. 
- The results of the quality of education reflect a degree of compliance of educational service to the employers' demands, state standards and consumers' demands.

- The rates of education conditions characterize the degree of compliance of the accepted conditions of study and labour and also modern equipment provision, sanitary, ecological and safety terms and also modern educational equipment, availability and quality of scientific literature.

- The results may be defined by the demand of the university's graduates in a particular profession in the market of labour.

- The potential of the university is estimated by methodological, scientific, pedagogical, management and economic activity.

- The adaptivity rates of an educational institution is reflected by the time of reaction to quickly changing social needs.

In many ways the ability of a university of adequate adaptation to the changing conditions of external environment is reflected by a system of rates, which characterise its competitiveness. In other words, if a university is capable to adapt quickly to the constantly changing conditions, that is also reflected on its competitiveness level.

An important sign showing the essential content of the notion of "a universities' competitiveness" are first of all superiority over competitors by a number of defining rates: financial, economic, marketing-related, material, technical, human, social and political. Secondly, a university has to function in a non-crisis way. Lastly, it has to have an ability of an adequate adaptation to the changing conditions of the environment.

Considering all the above, the author suggests the following definition of a university's competitiveness. A university's competitiveness is its general characteristic (on a particular time period in the particular labour market conditions and conditions of realization of definite educational services), reflecting its priority over competitive universities in educational services, an ability to realize successfully and to implement new innovation educational programmes, to use modern information and communication technologies and to react accordingly to the changing conditions of the environment.

\section{DIFFERENCES BETWEEN HIGH RATED AND LOW RATED UNIVERSITIES}

Results of research on higher educational institutions suggest the presence of a particular development strategy among the leading universities. I.e. any university in this or that way expresses its mission in order to help as many society members as possible to learn about its mission. Analysis made by an international universities association showed basic differences in objectives of the "leading universities" (highly rated) and "non-leading universities".
Leading universities aims differ from the "non-leading" ones by seeing themselves as co-creators of the students' future professional career, while the second ones traditionally aim to prepare students for life in general. The "leaders" consider the terms of a global economic society, while the "non-leaders" think in the categories of society in general. The lack of a clear perspective of the new qualities that a student acquires when leaving an educational course makes an educational institutions more attractive for the education consumers. $\{11\}$.

The best universities see its strategic objective in really giving their graduates a chance to be competitive in the dynamically developing global market economy. In such universities an educational standard became a complex educational product $=$ theoretical knowledge $=$ practice $=$ career. Only the universities with developed business connections line, professional orientation, practice and students" positioning may overcome such "entrance barriers" into the modern educational industry. Besides, an advantage is given to universities which actively use information and communication technologies in education. These technologies are considered as student cost reduction by moving educational material into an online environment.

An efficient participation in the innovative development processes demands firstly its specialists' practical foundation of their profession, secondly, the profound study of the perspective methods of their specialization, thirdly, an additional way of acquiring knowledge and skills which are necessary for successful work and competition in the Russian market. In this model an activity of the created "techno-structure" is an innovation education centre with an organizational, scientific and methodological provision of innovative academic activity of a university.

\section{CONCLUSION}

The provided analysis showed that competitiveness in the market of educational organization depends on an educational services realization plan. A result that follows is that in modern conditions without consideration of the specifics of educational services and active utilization of marketing instruments an educational institution is practically incapable of winning in this competitive battle and to gain its niche in the market. Therefore the following aspects should be considered:

- An effective marketing police should be provided.

- Already existing and innovative educational programmes should be implemented, modern information and communication technologies should be used to react adequately to the changing environment.

- Educational services and additional services should be provided together, which accompany and make the process of education more noble - providing living and cultural needs of the consumers and therefore adding to the competitiveness of the university.

- Teachers and professors should work to their best and show their competitiveness, competencies, 
communicativeness, friendliness, self-possession, call trust, etc.

- The expected volume of sales and market share on the basis of this data should already be forecasted on the stage of an educational service project.

- The competitiveness on different stages of a life cycle of an educational service should be managed.

\section{REFERENCES}

[1] Asaul A.N., Kaparov B.M. Higer educational institution management in the conditions of innovational economy. Spb: Humanistics, 2007. 280 pp.

[2] Blinov O.A., Blagireva E.N., Rudakova O.S. Interactive Methods in Educational Process. Methodology Book. Moscow, Scientific Library, 2014. pp 3-7.

[3] Zavgorodnaya A.V., Mieryn L.A. Technologies`s Transfer and Innovations Effective Realization in the Higher School// SaintPetersbourg News of the Economics and Finance University. 2000. \#1, pp.63-75.

[4] Kotler F. Marketing Basics. Moscow, Progress, 1990.

[5] Meskon M.X, Albert M., Hedwary F. Management Basics. Moscow, 1992, p. 602.

[6] Moskvichev Yu.A., Rozumov S.V > A University Efficiency Increase - a Complex Approach// Education in Information Age. Yaroslavl, 2001, p.59.

[7] Federal Law from 29.12.2012 \#273-FZ (edited on 31.12.2014) "On Education in Russian Federation" (came into power from 31.03.2015).

[8] Filatov S. Regional Models of teh Market of Educational Services// Higher Education in Russia. 2003 \#5. 